\section{Studia}

\section{z Filologii Polskiej i Słowiańskiej}

DOI: $10.11649 /$ sfps.2575
Studia z Filologii Polskiej i Słowiańskiej, 56

Warszawa 2021

Article No. 2575

Citation:

Augustyniak-Żmuda G. (2021). Różnorodność językowa przesiedleńców z dawnych wschodnich województw II Rzeczypospolitej: Fonetyka. Studia z Filologii Polskiej i Słowiańskiej, 56, Article 2575. https://doi.org/10.11649/sfps.2575

\author{
Gabriela Augustyniak-Żmuda \\ (Instytut Slawistyki Polskiej Akademii Nauk, Warszawa)
}

\title{
Różnorodność językowa przesiedleńców z dawnych wschodnich województw II Rzeczypospolitej. Fonetyka
}

W 2009 r. opublikowana została książka Mówi się. Porady językowe profesora Bralczyka (Bralczyk, 2009). Jedno z pytań, które pojawiło się w tym poradniku dotyczyło m.in. regionu lubuskiego: czy prawdą jest, że najczystszą polszczyzną mówią mieszkańcy Pomorza Zachodniego, Mazur i Ziemi Lubuskiej? (Bralczyk, 2009, s. 15). Prof. Bralczyk stwierdził, że na terenie Pomorza Zachodniego, na Ziemi Lubuskiej, na Dolnym Śląsku oraz na Mazurach mieszka głównie ludność napływowa, pochodząca zwłaszcza z dawnych wschodnich województw II Rzeczypospolitej. I pisze dalej:

Dialekty, które osiedleńcy przywieźli z własnych stron, nie miały oparcia w dialektach miejscowych, i dlatego na Ziemiach Odzyskanych, szybciej niż gdzie indziej, środkiem porozumiewania się - także w sytuacjach codziennych - stała się polszczyzna literacka. Możemy zatem powiedzieć, że mieszkańcy dawnych Ziem Odzyskanych najszybciej przestali mówić językiem gwarowym. Jeżeli za najczystszy uznamy język niegwarowy, nieposiadający cech dialektalnych,

This is an Open Access article distributed under the terms of the Creative Commons Attribution 3.0 PL License (creativecommons.org/licenses/by/3.0/pl/), which permits redistribution, commercial and non-commercial, provided that the article is properly cited. (c) The Author(s) 2021.

Publisher: Institute of Slavic Studies, Polish Academy of Sciences

[Wydawca: Instytut Slawistyki Polskiej Akademii Nauk] 
to pewnie lokalizacja „najczystszej polszczyzny” jest właśnie taka, jak pan podał (Bralczyk, 2009, ss. 15-16).

Będąc mieszkanką województwa lubuskiego, byłam pewna, że ów cytat nie przedstawia otaczającej mnie rzeczywistości językowej. Postanowiłam zatem sprawdzić, czy mieszkańcy regionu lubuskiego używają tylko języka literackiego.

Artykuł jest podsumowaniem socjolingwistycznych badań prowadzonych na terenie północnej części województwa lubuskiego w latach 2009-2019. Moimi rozmówcami były osoby urodzone w latach 1911-1942, które zostały przesiedlone z dawnych wschodnich województw II Rzeczypospolitej, tj. z województw: wileńskiego, nowogródzkiego, poleskiego, wołyńskiego, tarnopolskiego, lwowskiego, stanisławowskiego i białostockiego. Eksploracje terenowe prowadziłam w 23 miejscowościach: Bagniewo, Brzoza, Gardzko, Gorzów Wielkopolski, Krasnołęg, Krzeszyce, Lipno, Łagodzin, Łęgowo, Malta, Marwice, Muszkowo, Piskorzno, Różanki, Santok, Skwierzyna, Słońsk, Strzelce Klasztorne, Strzelce Krajeńskie, Studzionka, Świętojańsko, Witnica, Wojcieszyce.

Na materiał badawczy składają się 43 pogłębione wywiady o łącznej długości około 4800 minut (tj. 80 godzin). Idiolekty stanowią podstawowe źródło materiału empirycznego.

Celem niniejszego artykułu jest przedstawienie fonetycznej różnorodności językowej przesiedleńców z dawnych wschodnich województw II Rzeczypospolitej, spowodowanej odmiennymi biografiami językowymi rozmówców.

Prowadzone przeze mnie badania wymagały wykorzystania kilku metod badawczych. Podczas badań terenowych, gdy trudno jest odszukać członków interesującej eksploratora grupy, jedną z najbardziej adekwatnych metod jest kula śnieżna (snowball sampling) (Babbie, 2009, s. 213). Rozmówcy wskazują wówczas kolejne osoby, z którymi można przeprowadzić wywiad. Dzięki tej metodzie powstaje baza danych, utworzona przez akumulację rozmówców.

Drugą metodą, najbardziej dostosowaną do celu prowadzonych badań, był wywiad biograficzny, który wywodzi się z wywiadu otwartego (Kaufmann, 2010, s. 31). Wybór tej metody był podyktowany przede wszystkim wiekiem respondentów. Wykorzystanie metody badań ankietowych nie przyniosłoby tak dużej liczby informacji. Poza tym nie wszyscy rozmówcy byliby w stanie wypełnić ankietę. Wpływ na to mają doświadczenia życiowe informatorów oraz ich wiek. Wielu z nich ma problemy z czytaniem i pisaniem. W związku z tym metoda 
wywiadu biograficznego wydaje się najlepszym sposobem na zebranie materiału empirycznego. Wywiad w takiej formie skupia się na osobie będącej nie tylko podmiotem badań, lecz też interpretatorem społecznej rzeczywistości. Wywiad narracyjny wymusza na badaczu analizę doświadczeń i sposobu definiowania sytuacji przez samych rozmówców. Wykorzystując tę metodę, należy uwzględnić perspektywę badanego, przebieg jego życia oraz zjawiska społeczne, w jakie zaangażowana jest biografia informatora (zob. Hermanns, 1987; Schütze, 1977, 1983, 1984, 1987). Na rozwój wywiadu narracyjnego miały wpływ badania z zakresu historii mówionej (oral history), skupione na indywidualnych sposobach doświadczania wydarzeń historycznych i procesów makrospołecznych (zob. Thompson, 1978). Na podstawie wywiadu biograficznego badacz ma możliwość zrekonstruować czasowy porządek oraz sekwencje zdarzeń, które składają się na kolejne etapy biografii. Dlatego konieczne jest zebranie jak najbardziej pełnego zapisu uczestnictwa w łańcuchu zdarzeń i doświadczeń życiowych rozmówcy.

Nowatorskim podejściem jest potraktowanie biografii językowej jako metody, która umożliwia stworzenie szeregu szczegółowych opisów (zob. Franceschini \& Miecznikowski, 2004; Głuszkowski, 2011; Lewaszkiewicz, 2017; Meng, 2004; Norton, 2000; Zielińska, 2018). Przede wszystkim pozwala scharakteryzować sposoby oraz warunki nabywania i zanikania języków. $\mathrm{Na}$ podstawie biografii językowej można stworzyć historię mówienia jednostki w zależności od okresu życia oraz przedstawić problematykę nastawienia do języków. Dynamizacja eksploracji nad biografiami językowymi nastąpiła pod wpływem rozwoju badań nad wielojęzycznością.

Badania socjolingwistyczne mają to do siebie, że hipotezy powstają na podstawie zebranych danych empirycznych. Wraz z zaawansowaniem prac następuje weryfikacja i modyfikacja pojęć i teorii. Jest to metoda teorii ugruntowanej, dzięki której istnieje możliwość odkrycia czy znalezienia zjawisk niezaplanowanych na początku eksploracji. Dlatego niezwykle istotne jest zbieranie danych w sposób systematyczny (Glaser \& Strauss, 2009, s. XII; zob. Konecki, 2000). Wykorzystanie metody ugruntowanej w prowadzonych przeze mnie badaniach było konieczne, ponieważ przyjęcie określonej koncepcji w momencie rozpoczęcia eksploracji skutkowałoby skupieniem uwagi na konkretnych zjawiskach i tzw. wymuszeniem danych (forcing) (zob. Bukalska, 2015, s. 101). Mogłoby przez to dojść do niezauważenia istotnych procesów i zdarzeń ważnych przy badaniu biografii językowych przesiedleńców z dawnych wschodnich województw II Rzeczypospolitej. 
Na podstawie zebranego materiału socjolingwistycznego klasyfikowałam rozmówców według deklaracji wskazanego przez nich języka prymarnego ${ }^{1}$ przed przesiedleniem. Oznacza to, że lingwonimy, które są zastosowane w artykule, pochodzą z języka respondentów.

Tab. 1. Wskazanie liczby rozmówców, którzy deklarują język prymarny i sekundarny przed przesiedleniem

\begin{tabular}{|c|c|c|c|}
\hline \multicolumn{2}{|c|}{ Deklarowany } & \multirow{2}{*}{$\begin{array}{l}\text { Liczba } \\
\text { osób }\end{array}$} & \multirow{2}{*}{ Szyfr informatora } \\
\hline język prymarny & język sekundarny & & \\
\hline „prosty” & - & 1 & JS \\
\hline „poleski” & - & 2 & $\mathrm{AK}, \mathrm{KP}$ \\
\hline „ukraiński” & „polski” & 6 & PS, AD, AT, PR, PŻ, SW \\
\hline „chachłacki”2 & - & 5 & $\mathrm{BB}, \mathrm{SC}, \mathrm{PS}, \mathrm{AS}, \mathrm{JS} 1$ \\
\hline „białoruski” & „polski” & 2 & $\mathrm{OA}, \mathrm{PG}$ \\
\hline „polski” & „białoruski” & 1 & $\mathrm{MB}$ \\
\hline „polski” & „ukraiński” & 26 & $\begin{array}{l}\text { FŻ, JG, JG1, LL, PT, WG, AT, NM, MW, } \\
\text { LF, WF, CS, WI, AA, DS, KW, PL, SS, } \\
\text { WT, ZS, MW, ZK, HM, SJ, KG, SM }\end{array}$ \\
\hline
\end{tabular}

Po przetranskrybowaniu i analizie wszystkich 43 wywiadów zdecydowałam dokonać wyboru i prezentacji w pracy tych rozmów, które są reprezentatywne dla wytypowanych grup rozmówców. Celem takiego działania było ukazanie językowej

${ }^{1}$ Definicję języka prymarnego i języka sekundarnego podaję według L. Zawadowskiego: „Primary language is that one which individual uses for the basic range of subject (every day talking). It is the language used for home and family intercourse" (Zawadowski, 1961, s. 14). Język prymarny funkcjonuje w sferze rodziny i bez pośrednictwa innego języka jest przekazywany kolejnym pokoleniom (Zawadowski, 1961, ss. 9-15). L. Zawadowski w swojej definicji nie wskazuje konkretnej liczby języków prymarnych, które może posiadać jednostka. W związku $\mathrm{z}$ tym jedna osoba może posiadać dwa języki prymarne. Prymarności i sekundarności języka nie należy utożsamiać z kolejnością nabywania języków. Możliwe są sytuacje, gdy przez pewien okres życia funkcję języka prymarnego pełni $\mathrm{L}_{1}$, a potem w wyniku zmiany społecznej funkcję prymarną pełni $\mathrm{L}_{2}$.

${ }^{2}$ W rozumieniu przesiedleńców z dawnych wschodnich województw II Rzeczypospolitej mowa „chachłacka” jest językiem mieszanym, w którym występują elementy języka polskiego, ukraińskiego i rosyjskiego. Język „chachłacki” to także często używany potoczny lingwonim określający język ukraiński i jego odmiany. W wywiadach pojawia się także określenie „ruski”, które używane jest synonimicznie zarówno do ukraińskiego, rosyjskiego, jak i „chachłackiego”. O pojęciu tym pisał również M. Drzazgowski w artykule „O nazwie chachłacka mowa” (Drzazgowski, 1992). 
różnorodności przesiedleńców. Nie poddałam analizie lingwistycznej wszystkich 43 rozmów, ponieważ było to zbędne do ukazania różnorodności językowej.

Wyboru respondentów dokonałam za pomocą dwóch kryteriów. Najważniejszym kryterium wyboru respondenta były deklarowane języki używane przed przesiedleniem. Do przedstawienia analizy idiolektów wybrałam: a) 3 osoby z grupy deklarującej mówienie po „ukraińsku i polsku” - są to osoby, których językiem prymarnym przed przesiedleniem był język „ukraiński”, „polski” sekundarnym; b) przypadek osoby, która deklarowała „białoruski” jako język prymarny, a „polski” jako sekundarny; c) przypadek osoby, która deklarowała „polski” jako język prymarny, a „białoruski” jako sekundarny ${ }^{3}$; d) 3 osoby z grupy deklarującej mówienie po „polsku i ukraińsku” - są to osoby, które deklarowały „polski” jako język prymarny, „ukraiński” jako sekundarny; e) przypadek osoby, która deklarowała "polski” jako język prymarny, a „chachłacki” jako sekundarny.

Przesiedleńcy należą do najstarszej generacji, dlatego ustalenie grup o jednolitej wielkości nie było możliwe. Poniższa tabela przedstawia podstawowe informacje, dotyczące wybranych respondentów.

Tab. 2. Dane rozmówców

\begin{tabular}{|c|c|l|l|}
\hline $\begin{array}{c}\text { Szyfr } \\
\text { rozmówcy }\end{array}$ & $\begin{array}{c}\text { Rok } \\
\text { urodzenia }\end{array}$ & $\begin{array}{c}\text { Miejsce zamieszkania od narodzin } \\
\text { do przesiedlenia }\end{array}$ & $\begin{array}{c}\text { Miejsce zamieszkania w regio- } \\
\text { nie lubuskim (w trakcie prze- } \\
\text { prowadzania wywiadu) }\end{array}$ \\
\hline MB & 1932 & $\begin{array}{l}\text { woj. nowogródzkie, } \\
\text { Rudnia, pow. brzeski }\end{array}$ & Lipno \\
\hline OA & 1926 & $\begin{array}{l}\text { woj. nowogródzkie, } \\
\text { Jamiczno, pow. słonimski }\end{array}$ & Wojcieszyce \\
\hline AD & 1936 & $\begin{array}{l}\text { woj. tarnopolskie, } \\
\text { Olchowczyk, pow. husiatyński }\end{array}$ & Świętojańsko \\
\hline DS & 1929 & $\begin{array}{l}\text { woj. tarnopolskie, } \\
\text { Rasztowce, pow. husiatyński }\end{array}$ & Krasnołęg \\
\hline ZS & 1935 & $\begin{array}{l}\text { woj. tarnopolskie, } \\
\text { Słobódka Dolna, pow. buczacki }\end{array}$ & Świętojańsko \\
\hline MW & 1926 & $\begin{array}{l}\text { woj. lwowskie, } \\
\text { Kochawina, pow. żydaczowski }\end{array}$ & Piskorzno \\
\hline PZ & 1927 & $\begin{array}{l}\text { woj. stanisławowskie, } \\
\text { Kamionka Wielka, pow. kołomyjski }\end{array}$ & Piskorzno \\
\hline
\end{tabular}

3 W przypadku osób deklarujących mówienie po „białorusku i polsku” i „polsku i białorusku” na terenie regionu lubuskiego jest ich niewielu. Są to zatem mówcy szczególnie cenni, ponieważ posługują się zanikającymi wariantami języka polskiego. 


\begin{tabular}{|c|c|l|l|}
\hline $\begin{array}{c}\text { Szyfr } \\
\text { rozmówcy }\end{array}$ & $\begin{array}{c}\text { Rok } \\
\text { urodzenia }\end{array}$ & $\begin{array}{c}\text { Miejsce zamieszkania od narodzin } \\
\text { do przesiedlenia }\end{array}$ & $\begin{array}{c}\text { Miejsce zamieszkania w regio- } \\
\text { nie lubuskim (w trakcie prze- } \\
\text { prowadzania wywiadu) }\end{array}$ \\
\hline SW & 1921 & $\begin{array}{l}\text { woj. stanisławowskie, } \\
\text { Dąbrowa, pow. kałuski }\end{array}$ & Łęgowo \\
\hline SM & 1936 & $\begin{array}{l}\text { woj. stanisławowskie, } \\
\text { Kamionka Wielka, pow. kołomyjski }\end{array}$ & Krzeszyce \\
\hline
\end{tabular}

Wywiady z rozmówcami analizowałam pod względem występowania wybranych cech fonetycznych ${ }^{4}$, tj. zwężenia $o>u, e>y^{5}$ oraz $e>i^{6}$ w pozycji nieakcentowanej, asynchronicznej wymowy spółgłosek wargowych miękkich, przedniojęzykowo-zębowej artykulacji $t$, palatalnej wymowy spółgłoski $l$ przed samogłoskami, występowania dźwięcznej spółgłoski $\gamma$, palatalnej wymowy spółgłosek tylnojęzykowych.

Korpus tekstów, który został poddany analizie językoznawczej, obejmuje następujące części:

I. Wywiady z rozmówcami grupy mówiącej po „ukraińsku i polsku” wynoszą 4048 wyrazów.

II. Wywiad z osobą deklarującą mówienie po „białorusku i polsku” obejmuje 2775 wyrazów.

III. Wywiad z osobą deklarującą mówienie po „polsku i białorusku” to 2775 wyrazów. IV. Rozmowy z osobami deklarującymi mówienie po „polsku i ukraińsku” zostały przedstawione w liczbie $\mathbf{5 1 1 0}$ wyrazów dla każdego respondenta.

V. Wywiad z osobą deklarującą mówienie po „polsku i chachłacku” obejmuje 5069 wyrazów ${ }^{7}$.

${ }^{4}$ Głównym źródłem wyboru cech była pozycja Język polski na Ukrainie w końcu XX w., autorstwa J. Riegera, I. Cechosz-Felczyk i E. Dzięgiel (Rieger i in., 2007). Podstawową literaturą, w której poszukiwałam danej realizacji były książki i publikacje A. Zdaniukiewicza (Zdaniukiewicz, 1972), W. Paryla (Paryl, 1978), E. Homy (Homa, 1979), K. Kleszcza (Kleszcz, 2001), B. Wyderki (Wyderka, 2001), I. Grek-Pabisowej (Grek-Pabisowa, 2002), A. Zielińskiej (Zielińska, 2002), E. Dzięgiel (Dzięgiel, 2003), Z. Kurzowej (Kurzowa, 2006), K. Mority (Morita, 2006), H. Karaś (Karaś, 2017), T. Lewaszkiewicza (Lewaszkiewicz, 2017). Wszystkie analizowane w pracach wyżej wymienionych badaczy (zob. Bibliografia).

${ }^{5}$ Pod uwagę biorę również zwężenia $e>\dot{e}$ i $e>e^{y}$.

${ }^{6}$ Pod uwagę biorę również zwężenia $e>e^{i}$.

7 Na liczbę wyrazów składają się również pytania eksploratora, które nie podlegają analizie językowej, oraz fonetyczne znaki interpunkcyjne. Wynika to z wyliczeń programu edytorskiego Word. 


\section{W tabeli 3 przedstawiam po kilka wybranych przykładów ilustrujących} występowanie danej cechy.

\section{Tab. 3. Wybrane cechy fonetyczne (przykłady)}

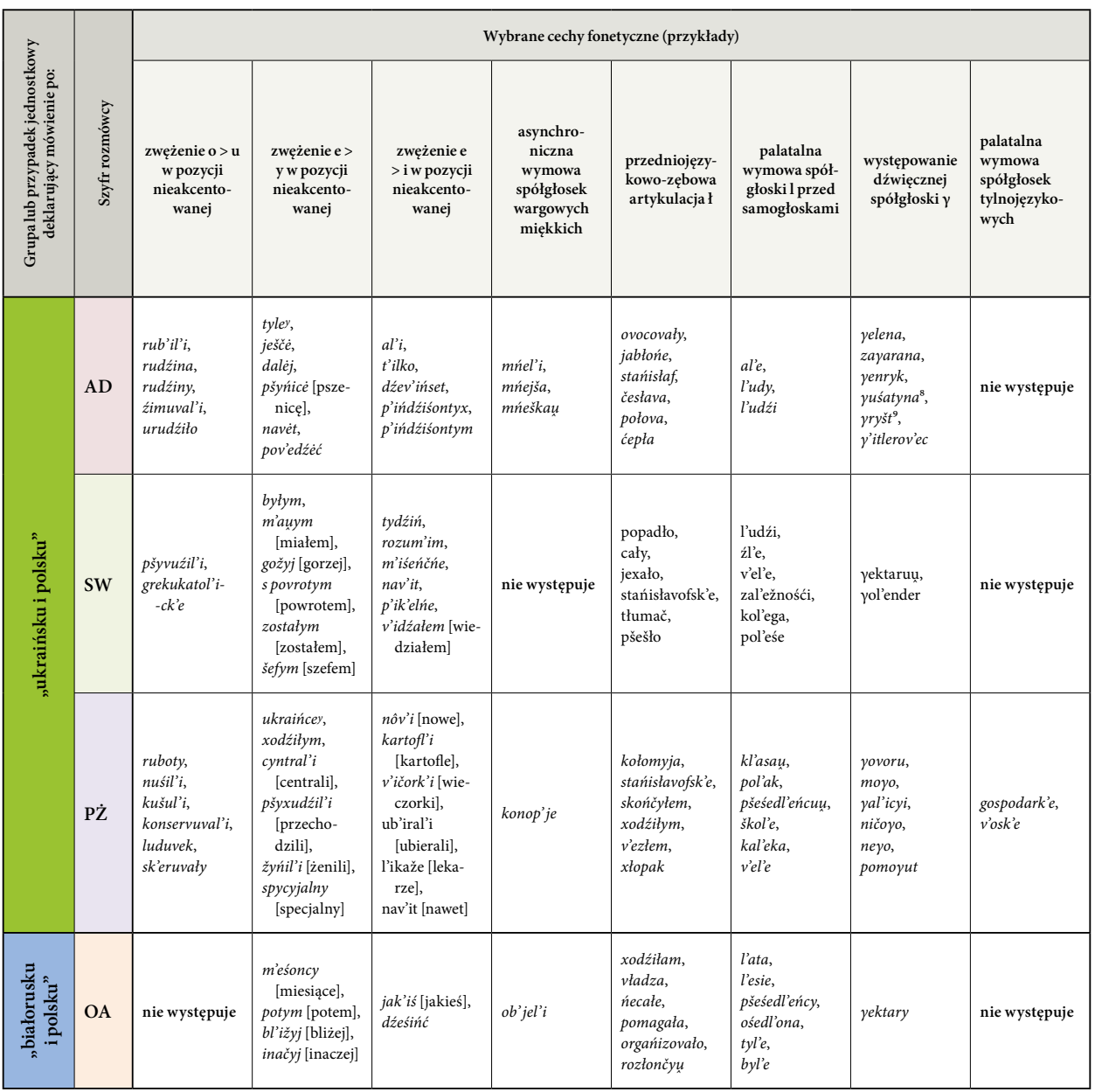

8 Husiatyn - nazwa miejscowości.

9 Hryszt - nazwisko. 


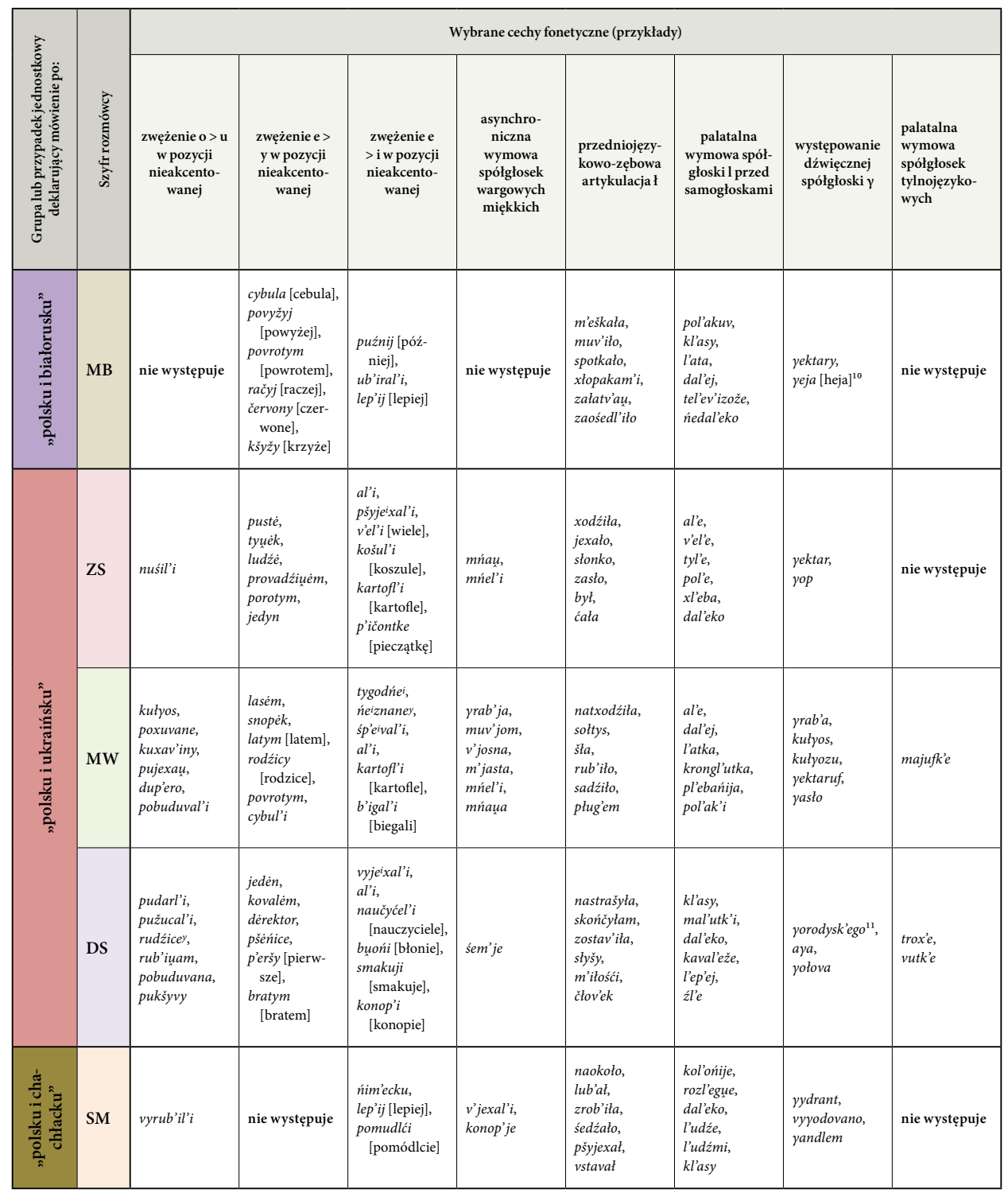

${ }^{10}$ Od wyrazu hej - wykrzyknik używany dla zwrócenia czyjejś uwagi.

11 Horodyski - nazwisko. 
Przy opisie systemu fonetycznego wykorzystuję analizę ilościową. Chcąc zachować wiarygodność wyników analizy liczbowej cech fonetycznych, przyjęłam liczbę możliwości wystąpienia $[\mathrm{LM}] \mathrm{z}$ wystąpieniem rzeczywistym [WR ${ }^{12}$. Wynik pozwolił mi na stworzenie procentowego i liczbowego podsumowania realizacji danej cechy. Korpus tekstów grup i przypadków indywidualnych różni się liczbą wyrazów, więc zestawienie liczbowe występowania danej cechy fonetycznej na tle wszystkich grup byłoby wynikiem nieprawidłowym. W celu przedstawienia intensywności występowania cech fonetycznych dla całej grupy dodałam łączną liczbę wystąpień rzeczywistych [WR] danej cechy w idiolektach rozmówców przypisanych do konkretnej grupy. Kolejno konieczne było dodanie liczby możliwych wystąpień [LM] danej cechy we wszystkich idiolektach każdej z grup. Skoro łączna liczba możliwych wystąpień cechy stanowi 100\% realizacji, należało określić, jaki procent stanowią wystąpienia rzeczywiste [WR]. W przypadku omówień jednostek, jak np. osoby deklarującej mówienie po „białorusku i polsku”, „polsku i białorusku”, „polsku i chachłacku”, to wartości procentowe stanowią wartości wykresów.

W celu dokładnego zobrazowania poniżej przedstawiam przykład obliczeń dla grup.

Wykres 1. Przedniojęzykowo-zębowa artykulacja $ł$ (zestawienie liczbowe grupy deklarującej mówienie po „ukraińsku i polsku”)

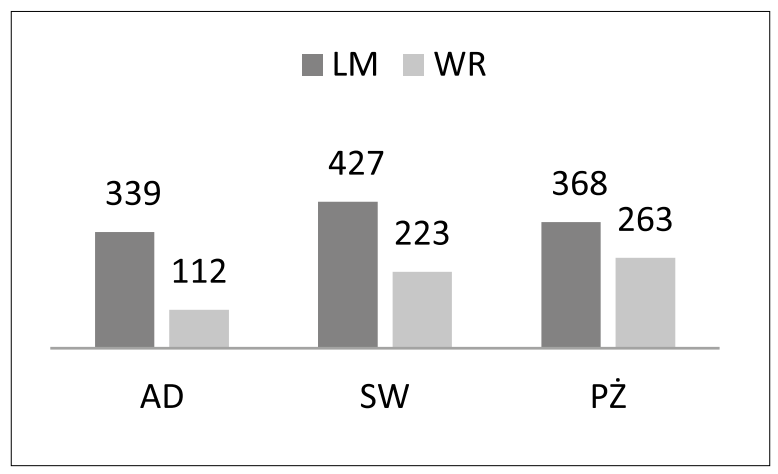

Wystąpienia rzeczywiste [WR] przedniojęzykowo-zębowej realizacji $t$ w grupie deklarującej mówienie po „ukraińsku i polsku” przedstawiają się następująco: AD 112, SW 223, PŻ 263. Łącznie jest to 598 wystąpień rzeczywistych [WR], tzn. przykładów, które wystąpiły we wszystkich idiolektach danej grupy.

12 Skrótów LM oraz WR używam przy tworzeniu schematów ilościowych. 
Kolejno należy policzyć możliwe wystąpienia [LM] przedniojęzykowo-zębowego t: AD 339, SW 427, PŻ 368. Łącznie w grupie „ukraińskiej i polskiej” $\ell$ mogło wystąpić 1134 razy we wszystkich idiolektach. Wartość możliwości wystąpień [LM] - 1134 jest równe $100 \%$. Należy zatem obliczyć, jaką wartość procentową stanowią wystąpienia rzeczywiste [WR] wśród wszystkich możliwości wystąpień [LM].

W tym przypadku równanie wygląda następująco.

$$
\begin{gathered}
598-\mathrm{x} \% \\
1134-100 \% \\
598 \cdot 100=59800 \\
59800: 1134=\mathbf{5 2 , 7 3 \%}
\end{gathered}
$$

Wynik oznacza, że w języku całej grupy deklarującej mówienie po „ukraińsku i polsku" przedniojęzykowo-zębowa artykulacja $l$ jest realizowana w 52,73\%. W celu porównania liczby realizacji cech fonetycznych wszystkich grup bilingwalnych, wynik procentowy przekładam na wynik liczbowy (tzn. 52,73\% = 52,73). Tylko w taki sposób można porównać wszystkie grupy dwujęzyczne. Wyliczenie występowania fonetycznych cech językowych, we wszystkich grupach rozmówców wykonane według omówionej powyżej metody, przedstawia poniższa tabela.

Tab. 4. Cechy fonetyczne - zestawienie idiolektów ${ }^{13}$

\begin{tabular}{|c|c|c|c|c|c|}
\hline \multirow{2}{*}{ Cecha fonetyczna } & \multicolumn{5}{|c|}{ Grupy } \\
\cline { 2 - 6 } & UP & BP & PB & PU & PCH \\
\hline zwężenie $o>u$ w pozycji nieakcentowanej & 1,08 & - & - & 2,27 & 0,11 \\
\hline zwężenie $e>y$ w pozycji nieakcentowanej & 1,86 & 0,82 & 1,42 & 2,74 & - \\
\hline
\end{tabular}

13 W tabelach 4 i 5 grupy rozmówców i przypadki jednostkowe oznaczam symbolami: UP - kategoria osób deklarujących mówienie po „ukraińsku i polsku”, BP - osoba deklarująca mówienie po „białorusku i polsku”, PB - osoba deklarująca mówienie po „polsku i białorusku”, PU - kategoria osób deklarujących mówienie po „polsku i ukraińsku”, PCH - osoba deklarująca mówienie po „polsku i chachłacku”. Do wymienionych skrótów nazw grup lub jednostek stosuję określenia: „ukraińska i polska”, „białoruska i polska”, „polska i białoruska”, „polska i ukraińska”, „polska i chachłacka”. 


\begin{tabular}{|l|c|c|c|c|c|}
\hline \multirow{2}{*}{ Cecha fonetyczna } & \multicolumn{5}{c|}{ Grupy } \\
\cline { 2 - 7 } & UP & \multicolumn{1}{c|}{ BP } & \multicolumn{1}{c|}{ PB } & \multicolumn{1}{c|}{ PU } & PCH \\
\hline zwężenie $e>i$ w pozycji nieakcentowanej & 1,96 & 0,27 & 1,16 & 3,7 & 0,2 \\
\hline $\begin{array}{l}\text { asynchroniczna wymowa spółgłosek wargo- } \\
\text { wych miękkich }\end{array}$ & 0,75 & 0,87 & - & 2,13 & 1,15 \\
\hline przedniojęzykowo-zębowa artykulacja $t$ & 52,73 & 95,28 & 36,9 & 39,23 & 5,68 \\
\hline $\begin{array}{l}\text { palatalna wymowa spółgłoski } l \text { przed samo- } \\
\text { głoskami }\end{array}$ & 19,48 & 25 & 18 & 18 & 3,48 \\
\hline występowanie dźwięcznej spółgłoski $\gamma$ & 100 & 100 & 100 & 109 & 100 \\
\hline $\begin{array}{l}\text { palatalna wymowa spółgłosek tylnojęzyko- } \\
\text { wych }\end{array}$ & 0,69 & - & - & 0,2 & - \\
\hline \multicolumn{1}{|c|}{ Liczba występowania cech fonetycznych } & $\mathbf{1 7 8 , 5 5}$ & $\mathbf{2 2 2 , 2 4}$ & $\mathbf{1 5 7 , 4 8}$ & $\mathbf{1 7 7 , 2 7}$ & $\mathbf{1 1 0 , 6 2}$ \\
\hline
\end{tabular}

Częstotliwość występowania analizowanych cech fonetycznych wygląda następująco:

I. przypadek osoby, która zadeklarowała mówienie po „białorusku i polsku” 222,24;

II. grupa deklarująca mówienie po „ukraińsku i polsku” - 178,55;

III. grupa deklarująca mówienie po „polsku i ukraińsku” - 177,27;

IV. przypadek osoby, która zadeklarowała mówienie po „polsku i białorusku" - 157,48;

V. przypadek osoby, która zadeklarowała mówienie po „polsku i chachłacku” 110,62 .

W idiolektach wszystkich grup odnotowałam bardzo mało przykładów zwężenia samogłosek $o>u, e>y$ i $e>i$ w pozycji nieakcentowanej. We wszystkich przeanalizowanych tekstach rozmówców bilingwalnych najwięcej przykładów zwężeń $o>u$ odnotowałam w grupie osób deklarujących przed przesiedleniem mówienie po „polsku i ukraińsku”. Najmniej odnotowałam w grupie „ukraińskiej i polskiej”. Znikome występowanie pojawiło się również w przypadku osoby, której językiem prymarnym przed przesiedleniem był "polski”, sekundarnym „chachłacki”. Ważnym zjawiskiem jest brak występowania cechy w przypadku osób, które miały kontakt językowy z językiem białoruskim. Zarówno w idiolekcie osoby deklarującej mówienie po „biało- 
rusku i polsku" oraz w mowie przesiedleńca, którego językiem prymarnym był „polski”, sekundarnym „białoruski” nie wystąpiły przykłady zwężenia $o>$ $u$ w pozycji nieakcentowanej. Różnice między idiolektami mają więc nie tylko ilościowy charakter. Są także różnice jakościowe, uzależnione od języków $\mathrm{z}$ okresu sprzed przesiedlenia.

Inaczej przedstawia się realizacja zwężenia $e>y \mathrm{w}$ pozycji nieakcentowanej. Największe nasilenie tej cechy wystąpiło w grupie „polskiej i ukraińskiej”. O wiele mniej przykładów odnotowałam w grupie „ukraińskiej i polskiej”. Najrzadziej cecha ta występuje w przypadku osób, które miały kontakt $\mathrm{z}$ językiem białoruskim. W tym przypadku częstotliwość zwężeń $e>y$ jest nieznacznie wyższa w idiolekcie osoby, której językiem prymarnym był język „polski”, sekundarnym „białoruski”. Najmniej przykładów wystąpiło w mowie osoby, która przed przesiedleniem mówiła po „białorusku i polsku”. Nie odnotowałam realizacji cechy w języku przesiedleńczyni deklarującej mówienie po „polsku i chachłacku".

W przypadku zwężenia $e>i$ w pozycji nieakcentowanej najbardziej cecha ta utrzymuje się $\mathrm{w}$ grupie przesiedleńców, których językiem prymarnym był „polski”, sekundarnym „ukraiński'. Na kolejnym miejscu plasuje się grupa „ukraińska i polska”. Zwężenia $e>i$ wystąpiły również w idiolekcie osoby deklarującej mówienie po „polsku i białorusku”. Najmniejsza częstotliwość cechy wystąpiła w mowie przesiedleńczyń, które zadeklarowały mówienie po „białorusku i polsku” i „polsku i chachłacku”.

Asynchroniczna wymowa spółgłosek wargowych miękkich najtrwalej utrzymuje się w języku grupy deklarującej mówienie po „polsku i ukraińsku”, a także w idiolekcie przesiedleńczyni deklarującej mówienie po „polsku i chachłacku". Cecha ta wystąpiła również w mowie kobiety, która przed przesiedleniem mówiła po „białorusku i polsku”. Najniższą wartość występowania cechy posiada grupa „ukraińska i polska”. Nie odnotowałam ani jednego przykładu realizacji asynchronicznej wymowy spółgłosek wargowych miękkich w przypadku mowy mężczyzny, którego językiem prymarnym był „polski”, sekundarnym „białoruski”.

Przedniojęzykowo-zębowa artykulacja $\downarrow$ jest w wielu idiolektach cechą systemową. W porównaniu wszystkich grup rozmówców, najczęściej występuje w idiolekcie kobiety, która zadeklarowała mówienie po „białorusku i polsku”. Kolejną grupą jest „ukraińska i polska”. Odnotowałam również znaczącą liczbę przykładów w mowie osób, których językiem prymarnym był „polski”, sekundarnym „ukraiński”. Najmniej realizacji cechy znajduje się 
w idiolektach osób deklarujących mówienie po "polsku i białorusku” oraz "polsku i chachłacku”.

Palatalna wymowa spółgłoski $l$ przed samogłoskami najczęściej jest realizowana przez grupę „białoruską i polską”. Drugą grupą, w mowie której można znaleźć tę cechę, jest „ukraińska i polska”. W idiolektach osób deklarujących mówienie po „polsku i białorusku” oraz „polsku i ukraińsku” palatalna wymowa spółgłoski $l$ jest realizowana na takim samym poziomie. Najmniej realizacji występuje w mowie przesiedleńczyni, której językiem prymarnym był „polski”, sekundarnym „chachłacki”.

Dźwięczna spółgłoska $\gamma$ najczęściej występuje w grupie „polskiej i ukraińskiej”. Wartość 100 oznacza (według przedstawionego wcześniej wyjaśnienia) $100 \%$ występowania danej cechy. W przypadku grupy deklarującej przed przesiedleniem mówienie po „polsku i ukraińsku” wartość realizacji dźwięcznej spółgłoski $\gamma$ wynosi 109, czyli jest realizowana w 109\%. Przy wyjaśnieniu posłużę się poniższym wykresem.

Wykres 2. Występowanie dźwięcznej spółgłoski $\gamma$ (zestawienie liczbowe grupy deklarującej mówienie po „polsku i ukraińsku”)

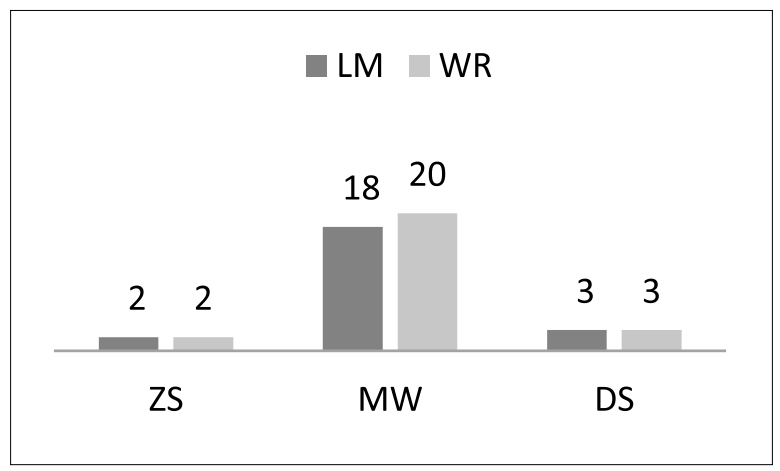

W przypadku ZS i DS liczba możliwych wystąpień [LM] i wystąpienia rzeczywiste [WR] są równe, tzn. ZS mógł użyć dźwięcznej spółgłoski $\gamma$ w 2 przykładach i tak się stało: yektar, yop. W przypadku DS dźwięczny wariant $\gamma$ mógł wystąpić w 3 przykładach, które odnotowałam: yorodysk'ego, aya, yołova. W idiolekcie MW liczba możliwych wystąpień wynosi 18 - w tylu przykładach mogła zostać użyta analizowana cecha, natomiast odnotowano aż 20 użyć: yrab'a (15 użyć), kułyos, kułyozu, yektaruf (2 użycia), yasło. Liczba możliwych wystąpień dla grupy wynosi 23 (tzn. 2+18+3), natomiast wartość rzeczywista 
wynosi 25 (tzn. 2+20+3). W związku z tym wartość realizowanej cechy wynosi 108,69\% (w zaokrągleniu 109). Zarówno w języku ukraińskim, jak i w wariancie polszczyzny południowokresowej, przeniesionej do regionu lubuskiego, spółgłoska $\gamma$ jest spirantem krtaniowym i tylnojęzykowym. W 1914 r. na występowanie tej cechy w polskich dialektach południowokresowych zwracał uwagę T. Lehr (Lehr, 1914). Zanik krtaniowości w mowie rozmówców, lub jego nadwyżka, zależy od różnych czynników. Już w 1932 r. J. Ziłyński zwracał uwagę na tę samą cechę, wskazując, że zanik dźwięczności zależny jest od czynników geograficznych lub indywidualnych (Ziłyński, 1932). Oddziaływanie języka ukraińskigo, którego skutkiem było występowanie dźwięcznej spółgłoski $\gamma$ w polszczyźnie południowokresowej, odnotowali Z. Kurzowa (Kurzowa, 2006), S. Rudnicki (Rudnicki, 2000), I. Cechosz-Felczyk (Cechosz, 2001) i E. Dzięgiel (Dzięgiel, 2001, 2003).

Przyjrzyjmy się kilku przykładom. E. Dzięgiel wyraz kołyosp odnotowuje jako leksykalne zapożyczenie z języka ukraińskiego (Dzięgiel, 2003, s. 151). W związku z tym wyrazy kołyos, kułyozu, które pochodzą z idiolektu MW, można traktować jako leksykalne zapożyczenie. Występujące przykłady użycia tej cechy odnoszą się do konkretnego okresu historycznego, jakim była praca w kołchozie. Powrót do takiego lub innego czasu w życiu człowieka często wyzwala słownictwo wraz z wszelkimi cechami lingwistycznymi charakterystycznymi dla danego okresu. Jest to zatem zależne od biografii językowej rozmówczyni. Zastępowanie $x$ przez $\gamma$ w przypadku MW odbywa się w sposób naturalny i nieświadomy. Nie prowadzi do zmiany znaczenia i nie jest zauważone przez użytkowniczkę języka.

We wszystkich innych grupach i przypadkach jednostkowych dźwięczne $\gamma$ jest realizowana $\mathrm{z}$ taką samą intensywnością (wynik wynosi 100, czyli jest realizowane $\mathrm{w} 100 \%)$. Jest to cecha systemowa wszystkich grup.

$\mathrm{Z}$ wywiadów wyekscerpowałam bardzo mało przykładów palatalnej wymowy spółgłosek tylnojęzykowych. Największy odsetek przykładów stanowią te, które wystąpiły w grupie „ukraińskiej i polskiej”. Najrzadziej cecha ta wystąpiła u przedstawicieli grupy „polskiej i ukraińskiej”. Osoby, które miały kontakt językowy z językiem białoruskim, nie realizują tej cechy, podobnie jak rozmówczyni deklarująca mówienie po „polsku i chachłacku”.

Z powyższego posumowania wynika, że w każdej grupie występowanie danej cechy było inne. W celu zobrazowania tego zjawiska poniżej przedstawiam tabelę $\mathrm{w}$ formie kolorystycznej wizualizacji. 
Tab. 5. Realizacja cech fonetycznych w idiolektach

\begin{tabular}{|c|c|c|c|c|c|c|c|c|c|}
\hline $\begin{array}{l}\text { Cecha fone- } \\
\text { tyczna }\end{array}$ & $\begin{array}{c}\text { I } \\
\text { Największa } \\
\text { częstotli- } \\
\text { wość } \\
\text { cechy }\end{array}$ & \multicolumn{4}{|c|}{$\begin{array}{c}\text { II } \\
\text { Duża częstotliwość } \\
\text { cechy }\end{array}$} & \multicolumn{2}{|c|}{$\begin{array}{c}\text { III } \\
\text { Srednia } \\
\text { częstotli- } \\
\text { wość cechy }\end{array}$} & $\begin{array}{l}\text { IV } \\
\text { Mała czę- } \\
\text { stotliwość } \\
\text { cechy }\end{array}$ & $\begin{array}{c}\mathrm{V} \\
\text { Najmniej- } \\
\text { sza czę- } \\
\text { stotliwość } \\
\text { cechy }\end{array}$ \\
\hline $\begin{array}{l}\text { zwężenie } o>u \mathrm{w} \\
\text { pozycji nieak- } \\
\text { centowanej }\end{array}$ & $\mathrm{PU}$ & \multicolumn{4}{|c|}{ UP } & \multicolumn{2}{|c|}{$\mathrm{PCH}$} & - & - \\
\hline $\begin{array}{l}\text { zwężenie } e>y \\
\text { w pozycji nieak- } \\
\text { centowanej }\end{array}$ & PU & \multicolumn{4}{|c|}{ UP } & \multicolumn{2}{|c|}{$\mathrm{PB}$} & $\mathrm{BP}$ & - \\
\hline $\begin{array}{l}\text { zwężenie } e> \\
i \text { w pozycji nie- } \\
\text { akcentowanej }\end{array}$ & PU & \multicolumn{4}{|c|}{ UP } & \multicolumn{2}{|c|}{$\mathrm{PB}$} & $\mathrm{BP}$ & $\mathrm{PCH}$ \\
\hline $\begin{array}{l}\text { asynchroniczna } \\
\text { wymowa spół- } \\
\text { głosek wargo- } \\
\text { wych miękkich }\end{array}$ & $\mathrm{PU}$ & \multicolumn{4}{|c|}{$\mathrm{PCH}$} & \multicolumn{2}{|c|}{$\mathrm{BP}$} & UP & - \\
\hline $\begin{array}{l}\text { przedniojęzy- } \\
\text { kowo-zębowa } \\
\text { artykulacja } t\end{array}$ & $\mathrm{BP}$ & \multicolumn{4}{|c|}{ UP } & \multicolumn{2}{|c|}{ PU } & $\mathrm{PB}$ & $\mathrm{PCH}$ \\
\hline $\begin{array}{l}\text { palatalna } \\
\text { wymowa spół- } \\
\text { głoski } l \text { przed } \\
\text { samogłoskami }\end{array}$ & $\mathrm{BP}$ & \multicolumn{4}{|c|}{ UP } & $\mathrm{PB}$ & $\mathrm{PU}$ & $\mathrm{PCH}$ & - \\
\hline $\begin{array}{l}\text { występowanie } \\
\text { dźwięcznej spół- } \\
\text { głoski } \gamma\end{array}$ & PU & UP & BP & PB & $\mathrm{PCH}$ & & & & \\
\hline $\begin{array}{l}\text { palatalna } \\
\text { wymowa spół- } \\
\text { głosek tylnojęzy- } \\
\text { kowych }\end{array}$ & UP & \multicolumn{4}{|c|}{ PU } & \multicolumn{2}{|c|}{-} & - & - \\
\hline
\end{tabular}

Szczegółowe analizy ilościowe dokonane na korpusach tekstów grup idiolektów i przypadków jednostkowych wykazały, że polszczyzna osób przesiedlonych po 1945 r. do regionu lubuskiego jest zróżnicowana zarówno pod względem ilościowym, jak i jakościowym.

Badania biografii językowych udowodniły, że szczególnie duży wpływ na kształtowanie się idiolektów języka polskiego mówców mają języki używane w okresie przed przesiedleniem. Znaczenie ma, który język był w dzieciństwie i młodości prymarny, a który sekundarny. Są też różnice jakościowe między 
idiolektami mówców dwujęzycznych polsko-białoruskich i polsko-ukraińskich. W polszczyźnie przesiedleńców obecne są do dzisiaj cechy będące rezultatem kontaktów językowych, pochodzące z języków ukraińskiego lub białoruskiego. Można zaobserwować także przełączanie kodów (zob. Augustyniak-Żmuda, 2020). Polszczyzna badanych osób jest tak zróżnicowana, że nawet trudno było podzielić je na jednorodne grupy. Artykuł przedstawia w sposób szczegółowy aktualny stan ich polszczyzny.

Badacze polszczyzny kresowej przeniesionej na zachodnie terytoria Polski dążyli w większości do przedstawienia i udowodnienia unifikacji i integracji językowej ${ }^{14}$. Nie uwzględniali przeszłości językowej przesiedleńców i widzieli w nich w miarę jednorodne grupy. Tymczasem odkrycie ich sytuacji językowej z okresu wcześniejszego i analiza źródeł polszczyzny pozwala poznać specyfikę ich języka. Badania językoznawcze były ukierunkowane na ukazanie jednorod-

14 Spójrzmy choćby na kilka prac. W artykule A. Zdaniukiewicza Procesy integracji językowej na Ziemiach Zachodnich i Północnych w świetle analizy ilościowej (Zdaniukiewicz, 1972) przedstawiono wyniki badań, podczas których eksploracjami objęto język przesiedleńców z Łopatowszczyzny, Boguszów i Hołowaczów. Pozostali rozmówcy byli dobrani ze środowiska, w którym żyli przesiedleńcy. Przy analizie zmian językowych nie podano informacji, charakteryzującej informatorów choćby pod względem pochodzenia (nie wiadomo, czy jest to przesiedleniec ze wschodnich województw II Rzeczypospolitej, czy osiedleniec z centralnej Polski bądź Wielkopolski). W związku z tym wnioski przedstawione w artykule są bardzo ogólne. Według E. Homy w pracy Współczesne gwary Pomorza Środkowego. Studium socjolingwistyczne adaptacja i integracja na terenie objętym jego badaniami przebiegły bardzo szybko. Język północno-zachodniej Polski to według badacza „nowa jakość systemowo-językowa, różna od tworzących ją składników. Powstały w ten sposób dialekt jest w swej strukturze bardzo zbliżony do języka literackiego" (Homa, 1979, s. 23). W badaniach E. Homy przesiedleńcy z dawnych wschodnich województw II Rzeczypospolitej zostali ujęci tylko w jednej kategorii - miejsca pochodzenia. Nie wyróżniono przesiedleńców, którzy przybyli z Syberii czy przymusowych robotników w Niemczech. Wszystkich dawnych mieszkańców wschodnich województw potraktowano jako grupę jednorodną pod względem pochodzenia i pod względem języka. Niewiele ponad 25 lat po przesiedleniu język nie mógł stać się „zbliżony do języka literackiego", ponieważ różnorodność językowa jest zauważalna do dziś (zob. Zielińska, 2013). Badania nad językiem przesiedleńców z dawnych wschodnich województw II Rzeczypospolitej prowadził także K. Kleszcz. W pracy Unifikacja języka mieszkańców wsi okolic Brzegu na Śląsku Opolskim. Studium socjolingwistyczne (Kleszcz, 2001) przedstawił opis zmian językowych zachodzących w języku ludności wysiedlonej po 1945 roku z powiatu Brzeżany, Gródek Jagielloński, Równe na teren Śląska Opolskiego. Według badacza zmiany społeczne istotnie wpłynęły na język wsi, przez co użytkownicy odchodzili od gwary na rzecz języka ogólnopolskiego. Badacz podczas zbierania materiału empirycznego nie postawił pytania o języki, których respondenci używali w okresie przed przesiedleniem. $Z$ tego powodu wszyscy przesiedleńcy uwzględnieni zostali jako grupa jednorodna. 
ności i integracji różnych odmian polszczyzny z wariantem ogólnym. Pogląd ten $\mathrm{w}$ świetle przeprowadzonych przeze mnie analiz wymaga rewizji.

Nie podjęto badań, które miałyby przedstawić wewnętrzną różnorodność językową przesiedleńców z dawnych wschodnich województw II Rzeczypospolitej, biorąc pod uwagę języki używane przed przesiedleniem. Nie uwzględniano przeszłości językowej mieszkańców nowych regionów Polski, a zwłaszcza nie dopuszczano możliwości, że ich znaczna część w ogóle nie znała języka polskiego lub była dwujęzyczna. We wszystkich badaniach nad językiem przesiedleńców traktowano ich jak jedną grupę mówiącą po polsku, co spowodowało przedstawienie ich mowy jako jednorodnej. Mając obecnie możliwość wykorzystywania różnorodnych metod badawczych, możemy prowadzić badania, w których najważniejszym elementem jest jednostka (mówca), a nie cała grupa.

\section{Bibliografia}

Augustyniak-Żmuda, G. (2020). Przełączanie kodów (code switching) w mowie przesiedleńców z województwa tarnopolskiego i stanisławowskiego, mieszkających w regionie lubuskim. Socjolingwistyka, 34, 261-273. https://doi.org/10.17651/SOCJOLING.34.16

Babbie, E. (2009). Podstawy badań społecznych (W. Betkiewicz, Tłum.). Wydawnictwo Naukowe PWN. Bralczyk, J. (2009). Mówi się: Porady językowe profesora Bralczyka. Wydawnictwo Naukowe PWN.

Bukalska, I. (2015). Metodologia teorii ugruntowanej a teoria Margaret S. Archer. Uniwersyteckie Czasopismo Socjologiczne, 2015(10), 100-104.

Cechosz, I. (2001). Polska gwara Oleszkowiec na Podolu: Fleksja imienna i werbalna. Wydawnictwo Naukowe PWN.

Drzazgowski, M. (1992). O nazwie chachłacka mowa. W K. Handke (Red.), Słowiańskie pogranicza językowe: Zbiór studiów (ss. 29-35). Wydawnictwo „Res Publica Press”.

Dzięgiel, E. (2001). Polska gwara wsi Zielonej na Podolu na tle innych gwar południowokresowych: Fleksja imienna $i$ werbalna. Wydawnictwo Naukowe PWN.

Dzięgiel, E. (2003). Polszczyzna na Ukrainie: Sytuacja językowa w wybranych wsiach chłopskich i szlacheckich. Wydawnictwo Naukowe Semper.

Franceschini, R., \& Miecznikowski, J. (Red.). (2004). Leben mit mehreren Sprachen: Sprachbiographien / Vivre avec plusieurs langues: Biographies langagières. Peter Lang.

Glaser, B. G., \& Strauss, A. L. (2009). Odkrywanie teorii ugruntowanej: Strategie badania jakościowego (M. Gorzko, Tłum.). Zakład Wydawniczy „Nomos”.

Głuszkowski, M. (2011). Socjologiczne i psychologiczne uwarunkowania dwujęzyczności staroobrzędowców rejonu suwalsko-augustowskiego. Wydawnictwo Naukowe Uniwersytetu Mikołaja Kopernika. 
Grek-Pabisowa, I. (2002). Współczesne gwary polskie na Litwie i Białorusi: Fonetyka. Instytut Slawistyki Polskiej Akademii Nauk (Slawistyczny Ośrodek Wydawniczy).

Hermanns, H. (1987). Narrative interview: A new tool for sociological field research. Folia Sociologica, 1987(13), 43-56.

Homa, E. (1979). Współczesne gwary Pomorza Środkowego: Studium socjolingwistyczne (Cz. 1). Wyższa Szkoła Pedagogiczna w Słupsku.

Karaś, H. (2017). Język polski pogranicza litewsko-łotewsko-białoruskiego w świetle frekwencji cech językowych. Wydział Polonistyki Uniwersytetu Warszawskiego.

Kaufmann, J.-C. (2010). Wywiad rozumiejacy (A. Kapciak, Tłum.). Oficyna Naukowa.

Kleszcz, K. (2001). Unifikacja języka mieszkańców wsi okolic Brzegu na Śląsku Opolskim: Studium socjolingwistyczne. Wydawnictwo Uniwersytetu Opolskiego.

Konecki, K. (2000). Studia z metodologii badań jakościowych: Teoria ugruntowana. Wydawnictwo Naukowe PWN.

Kurzowa, Z. (2006). Polszczyzna Lwowa i Kresów południowo-wschodnich do 1939 roku. Towarzystwo Autorów i Wydawców Prac Naukowych „Universitas”.

Lehr, T. (1914). O mowie Polaków w Galicji wschodniej. Język Polski, 2, 40-51.

Lewaszkiewicz, T. (2017). Język powojennych przesiedleńców z Nowogródka i okolicy. Wydawnictwo Naukowe Uniwersytetu im. Adama Mickiewicza.

Meng, K. (2004). Russlanddeutsche Sprachbiographien - Rückblick auf ein Projekt. W R. Franceschini \& J. Miecznikowski (Red.), Leben mit mehreren Sprachen: Sprachbiographien I Vivre avec plusieurs langues: Biographies langagières (ss. 97-117). Peter Lang.

Morita, K. (2006). Przemiany socjolingwistyczne w polskich społecznościach na Litwie (region trocki) i Białorusi (region iwieniecki): Studium porównawcze. Instytut Slawistyki Polskiej Akademii Nauk (Slawistyczny Ośrodek Wydawniczy).

Norton, B. (2000). Identity and language learning: Social processes and educational practice. Longman.

Paryl, W. (1978). Oddziaływanie języka literackiego na niektóre dialekty Ziem Zachodnich. Studia Linguistica, 4, 71-82.

Rieger, J., Cechosz-Felczyk, I., \& Dzięgiel, E. (2007). Język polski na Ukrainie w końcu XX wieku: Cz. 2. Polszczyzna w Lwowskiem, Żytomierskiem i na Podolu: Teksty. Wydawnictwo Lexis.

Rudnicki, S. (2000). Gwara polska wsi Korczunek koło Żytomierza. Instytut Slawistyki Polskiej Akademii Nauk (Slawistyczny Ośrodek Wydawniczy).

Schütze, F. (1977). Die Technik des narrativen Interviews in Interaktionsfeldstudien dargestellt an einem Projekt zur Erforschung kommunalen Machtstrukturen. W Arbeitsberichte und Forschungsmaterialien (ss. 1-62). Universität Bielefeld, der Fakultät für Soziologie der Universität.

Schütze, F. (1983). Biographieforschung und narratives Interview. Neue Praxis, 13(3), 283-293.

Schütze, F. (1984). Kognitive Figuren des autobiographischen Stegreiferzählens. W M. Kohli \& G. Robert (Red.), Biographie und soziale Wirklichkeit: Neue Beiträge und Forschungsperspektiven (ss. 78-117). Metzler. 
Schütze, F. (1987). Das narrative Interview in Interaktionsfeldstudien I. Fernuniversität Hagen. Thompson, P. (1978). The voice of the past: Oral history. Oxford University Press.

Wyderka, B. (2001). Przemiany językowe na ziemiach zachodnich i północnych. W S. Gajda (Red.), Najnowsze dzieje języków słowiańskich: Język polski (ss. 460-476). Uniwersytet Opolski.

Zawadowski, L. (1961). Fundamental relations in language contact. Biuletyn Polskiego Towarzystwa Językoznawczego, 20, 3-26.

Zdaniukiewicz, A. A. (1972). Procesy integracji językowej na Ziemiach Zachodnich i Północnych w świetle analizy ilościowej. Prace Filologiczne, 23, 283-288.

Zielińska, A. (2002). Polska mniejszość na Litwie Kowieńskiej: Studium socjolingwistyczne. Instytut Slawistyki Polskiej Akademii Nauk (Slawistyczny Ośrodek Wydawniczy).

Zielińska, A. (2013). Mowa pogranicza: Studium o jezzykach i tożsamościach w regionie lubuskim. Instytut Slawistyki Polskiej Akademii Nauk (Slawistyczny Ośrodek Wydawniczy).

Zielińska, A. (2018). Biografie językowe osób bilingwalnych z polsko-niemieckiego pogranicza. W Z polskich studiów slawistycznych: Seria 13, T. 2. Językoznawstwo: Prace na XVI Międzynarodowy Kongres Slawistów w Belgradzie 2018 (ss. 359-268). Wydawnictwo Naukowe Uniwersytetu im. Adama Mickiewicza.

Ziłyński, J. (1932). Opis fonetyczny języka ukraińskiego. Wydawnictwo Polska Akademia Umiejętności.

\section{Linguistic Diversity of People Resettled from the Former Eastern Provinces of the Second Polish Republic: Phonetics}

\section{Summary}

This article is a summary of a sociolinguistic study conducted in the northern part of the Lubusz region in 2009-2019. The study concerned the linguistic diversity of people resettled after 1945 from the former eastern provinces of the Second Polish Republic to the Lubusz region. The informants were people from the oldest generation who were born between 1911 and 1942 in the former Polish administrative provinces in the east of pre-war Poland: Wilno (Vilnius), Nowogródek (Navahrudak), Polesia, Volhynia, Tarnopol (Ternopil), Lwów (Lviv), Stanisławów (today: Ivano-Frankivsk) and Białystok. 
As described, the interdisciplinary nature of the study required the use of several research methods: field research, biographical interview, linguistic biography, grounded theory, and methods of idiolect analysis (quantitative analysis). On the basis of the collected sociolinguistic material, the interlocutors are classified according to their self-declared primary language prior to the resettlement. This means that the linguonyms used in the article come from the language of the respondents. Accordingly, the following groups are distinguished: speakers of (1) Ukrainian and Polish, (2) Belarusian and Polish, (3) Polish and Belarusian, (4) Polish and Ukrainian, (5) Polish and Khakhlak. Based on a quantitative analysis, the article presents the linguistic diversity in the Lubusz region.

\section{Różnorodność językowa przesiedleńców $\mathrm{z}$ dawnych wschodnich województw II Rzeczypospolitej. Fonetyka}

\section{Streszczenie}

Artykuł jest podsumowaniem socjolingwistycznych badań prowadzonych na terenie północnej części województwa lubuskiego w latach 2009-2019. Badania dotyczyły różnorodności językowej wśród osób przesiedlonych po 1945 r. z dawnych wschodnich województw II Rzeczypospolitej do regionu lubuskiego. Moimi rozmówcami były osoby urodzone w latach 1911-1942 na terenie województw: wileńskiego, nowogródzkiego, poleskiego, wołyńskiego, tarnopolskiego, lwowskiego, stanisławowskiego i białostockiego. Charakter interdyscyplinarnych badań wymagał wykorzystania kilku metod badawczych. W artykule można znaleźć opis metody badań terenowych, metody wywiadu biograficznego, metody biografii językowej, metody teorii ugruntowanej oraz metody analizy idiolektów (analizy ilościowej). Na podstawie zebranego materiału socjolingwistycznego klasyfikowałam rozmówców według deklaracji wskazanego przez nich języka prymarnego przed przesiedleniem. Oznacza to, że lingwonimy użyte $\mathrm{w}$ artykule pochodzą z języka respondentów. W taki sposób wyróżniłam grupę deklarującą mówienie 1) po ukraińsku i polsku, 2) po białorusku i polsku, 3) po polsku i białorusku, 4) po polsku i ukraińsku 
oraz 5) po polsku i chachłacku. Na podstawie analizy ilościowej przedstawiam $\mathrm{w}$ artykule różnorodność językową w regionie lubuskim.

Keywords: linguistic diversity; resettled people; Lubusz region

Słowa kluczowe: różnorodność językowa; przesiedleńcy; region lubuski

Gabriela Augustyniak-Żmuda, Institute of Slavic Studies, Polish Academy of Sciences, Warsaw, Poland ORCID: https://orcid.org/0000-0001-9920-6663

Correspondence: gabriela.augustyniak-zmuda@ispan.waw.pl

The preparation of this article was self-financed by the author.

Competing interests: The author has declared that she has no competing interests.

Publication history: Received: 2021-05-14; Accepted: 2021-08-25; Published: 2021-12-20 